\title{
KINETIC INVESTIGATION OF CARBON DIOXIDE, ACETIC ACID, ACRYLIC ACID FORMATION ON DILUTED AND LEACHED MOVTeNb CATALYST
}

\author{
Restu Kartiko Widi \\ Department of Chemical Engineering, Faculty of Engineering, University of Surabaya (UBAYA), \\ TG Building $6^{\text {th }}$ floor, JIn. Raya Kalirungkut Tenggilis, Surabaya, 60293, Indonesia
}

Received January 24, 2012; Accepted February 8, 2012

\begin{abstract}
Reaction kinetics for the oxidation of propane over diluted-leached MoVTeNb is described. This paper is focused on the study of determination of the orders of carbon dioxide, acetic acid and acrylic acid formation. Deep oxidation of propane to carbon dioxide is first order with respect to hydrocarbon, and partial order (0.31) with respect to oxygen. The selective oxidation of propane to acrylic acid is partial order (0.49) with respect to hydrocarbon and partial order (0.09) with respect to oxygen.
\end{abstract}

Keywords: propane oxidation; catalyst; selective oxidation; kinetic; acrylic acid

\begin{abstract}
ABSTRAK
Telah dipaparkan kinetika reaksi oksidasi propana pada katalis MoVTeNb dengan pengemban dan pembilasan. Artikel ini fokus pada studi penentuan orde reaksi pembentukan karbon dioksida, asam asetat dan asam akrilat. Oksidasi lanjut propana menjadi karbon dioksida mengikuti reaksi orde pertama terhadap hidrokarbon dan orde parsial $(0,31)$ terhadap oksigen. Sedangkan oksidasi propana menjadi asam akrilat mengikuti orde parsial baik terhadap hidrokarbon maupun oksigen, masing-masing sebesar 0,49 dan 0,09.
\end{abstract}

Kata Kunci: oksidasi propana; katalis; oksidasi selektif; kinetika; asam akrilat

\section{INTRODUCTION}

The selective oxidation of light alkanes $\left(C_{1}-C_{5}\right)$, especially propane, to form the corresponding olefins, alcohols, aldehydes, anhydrides or acids has been largely studied in the past 20 years for two main reasons. The first one is economical since alkanes are much cheaper and more abundant than the corresponding olefins. The second one is fundamental since the way by which the alkane is activated and functionalized into an oxygenate remains unclear and challenging [1].

Many factors play a role in selective oxidation reactions on metal oxide catalysts and the complexity of such catalysts is widely recognized [2]. A number of assumptions on how the MoVTeNb catalyst works suggested [3-5]

In the previous article, it has been described the reaction kinetics and mechanism of propane partial oxidation to acrylic acid on diluted MoVTeNbOx mixedoxide catalysts using high-throughput system (nanoflow reactor) [6]. This article more focus and deals with the similar reaction oxidation over diluted and leached MoVTeNbOx mixed-oxide catalysts. This paper is the second part and focused on the study of determination of the orders of carbon dioxide, acetic acid and acrylic acid formation divided into two parts. Part one which is focused on the profile of products selectivity, the rate of propane disappearance and the rate of propene formation has been reported [7].

\section{EXPERIMENTAL SECTION}

\section{Materials}

Steam (demineralized water), Nitrogen $(99.9 \%$, MOX-Malaysian Oxygen Bhd), Propane (98.9\%, MOXMalaysian Oxygen Bhd), Oxygen (99.9\%, MOXMalaysian Oxygen Bhd).

\section{Instrumentation}

Nanoflow catalytic reactor on-line with gas chromatography (HP6890-Agilent Technology).

\section{Procedure}

The preparation of Diluted $\mathrm{Mo}_{1} \mathrm{~V}_{0.30} \mathrm{Te}_{0.23} \mathrm{Nb}_{0.125} \mathrm{O}_{x}$ and its characterization have been described in more detail before [8-9]. In addition, in this article the catalyst

* Corresponding author. Tel/Fax : +62-312981398/312981387

Email address : restu@ubaya.ac.id 
Table 1. Apparent activation energy

\begin{tabular}{lc}
\hline Process & Activation energy $\left(\mathrm{kJ.} \mathrm{mol}^{-1}\right)$ \\
\hline Propane disappearance & 27.3 \\
Propene formation & 40.9 \\
$\mathrm{CO}_{2}$ formation & 177.3 \\
Acetic acid formation & 91.6 \\
Acrylic acid formation & 30.3 \\
\hline
\end{tabular}

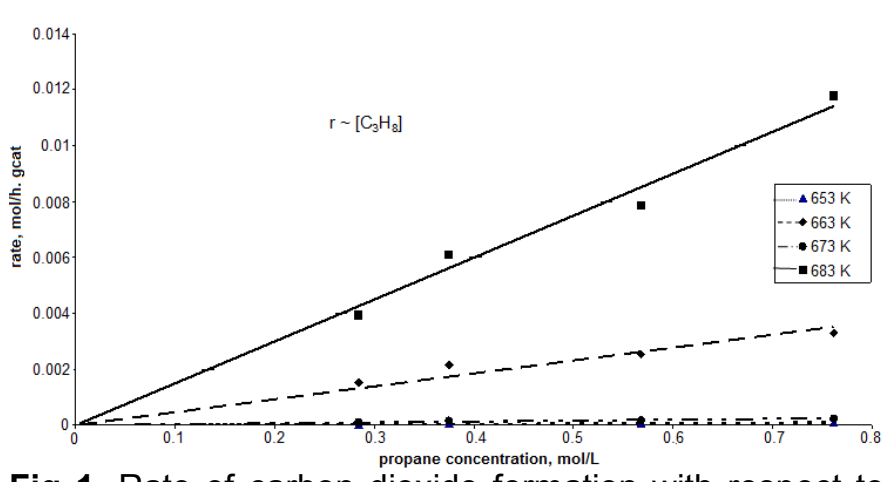

Fig 1. Rate of carbon dioxide formation with respect to propane concentration at $653,663,673$, and $683 \mathrm{~K}$

preparation is followed by leaching process using water for $1 \mathrm{~h}$, and then it is dried and calcined according to the method described in the previous literature. The kinetic studies were conducted by analysis of the products at low propane and oxygen concentrations (lower than $10 \%)$, which is required for operating the reactor in a differential mode. This was achieved by introducing small amount of catalyst $(0.09 \mathrm{~g})$ diluted in $\mathrm{SiO}_{2}$ to a total volume of $0.5 \mathrm{~mL}$ and using high total flow rates $15 \mathrm{mLN} / \mathrm{min}$ and Gas Hourly Space Velocity (GHSV) of $1800 \mathrm{~h}^{-1}$. Gas hourly space velocity (GHSV) is defined as the ratio of the volumetric flow rate of reactants at standard conditions to the total catalyst volume yielding a quantity with units of inverse time [13]. By this definition, it means, the higher GHSV the higher volumetric flow rate is. As a consequence, the contact time between gas feed and catalyst surface (active site) will be less by increasing the GHSV value.

Only one of the reactants was varied at the time and the rest were chosen to be in excess and outside of the explosive limits for the mixture of propane and oxygen. The feed composition was propane, oxygen, and steam (water) balance in nitrogen. The study of the kinetic dependence on propane was performed by varying the propane concentration and maintaining the others. For the oxygen dependence, oxygen concentration was varied and concentrations of the others were maintained. Finally, for the water dependence, water concentration was varied and concentrations of the others were maintained. The effect of reactant concentration was studied at four different temperatures, i.e., 653, 663, 673, and $683 \mathrm{~K}$. Particle size of catalytic material was $212-425 \mu \mathrm{m}$ or less $[6,9]$.
For all experimental results, the reaction rate and the concentration of reactants are calculated using Equations shown below:

Reaction rate $\left(\mathrm{mol} / \mathrm{h} . \mathrm{g}_{\text {cat }}\right)=\frac{\% \text { vol } \times \text { total gas flow } \times \mathrm{d} \times 60}{\mathrm{Mr} \times \text { catalyst weight }}(1)$

Concentration $(\mathrm{mol} / \mathrm{L})=(\% \mathrm{vol} \times \mathrm{d} \times 1000) / \mathrm{Mr}$

where, \%vol is concentration of product in \% (v/v); total gas flow is the total flow of product stream from the reactor in $\mathrm{mLN} / \mathrm{min}$; $\mathrm{Mr}$ and $\mathrm{d}$ are molecular weight and density of the product; and catalyst weight is the weight of catalyst in gram.

The activation energy is determined experimentally by carrying out the reaction at several different temperatures. After taking the natural logarithm of equation

$\ln \mathrm{k}=\ln \mathrm{A}-\frac{\mathrm{Ea}}{\mathrm{R}}\left(\frac{1}{\mathrm{~T}}\right)$

\section{RESULT AND DISCUSSION}

The structure and surface texturing of MoVTeNb oxide catalyst particles composed of two phases referred to in the literature as $M 1$ and $M 2$. The $M 1$ phase is the cluster that active as catalyst for the conversion of propane to acrylic acid [10-11]. Chemical composition of the catalyst surface is modified by treatment in water to obtain a significant increment in yield of acrylic acid. The process is called as leaching. It means the leaching process using water for $1 \mathrm{~h}$ support to release the M2 phase from the catalyst. It can be expected that the catalyst more active since only M1 phase stay in the catalyst. This phenomenon has been reported clearly by Jacob and coworkers [8]. The paper showed the SEM images of diluted catalyst before and after leaching and it showed that the distribution of catalyst was improved by leaching. The paper also showed high-resolution images of the termination of M1. It was clearly observed such structural rearrangement to exist at the surface of the M1 and the M2 phase [8]. The reproducibility of catalytic activity test has been carried out by repeated the experiments under the same condition and showed very good reproducibility in terms of both the propane conversion and acrylic acid selectivity [9].

In part one, it has been described the product selectivity profiles for propane oxidation over diluted and leached MoVTeNb oxide catalyst under reactor differential mode. According to the data, the reaction can be proposed by the following reaction $\mathrm{C}_{3} \mathrm{H}_{8}+\mathrm{O}_{2} \rightarrow$ products, where the products are propene, acrylic acid, acetic acid, and carbon dioxide [7].

Table 1 depicts the activation energy which is needed in the total reaction, i.e. oxidation of propane to acrylic acid. 


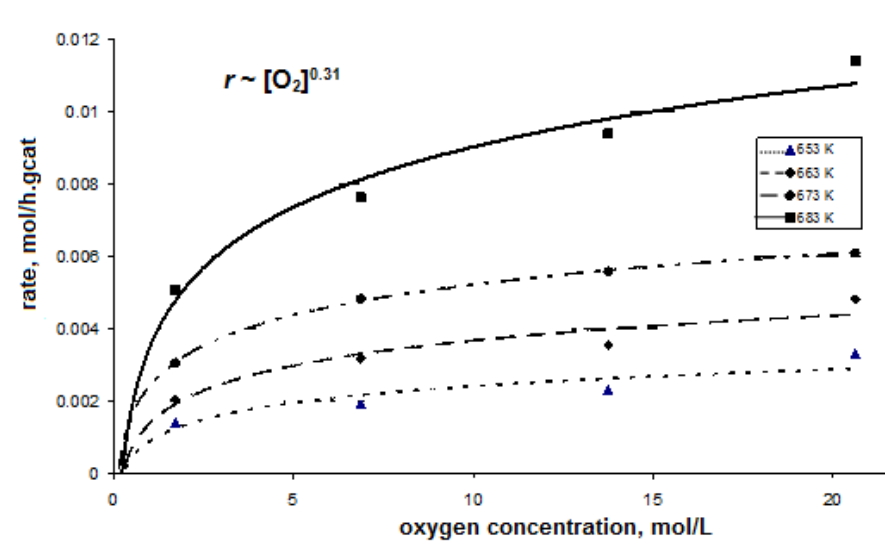

Fig 2. Rate of carbon dioxide formation with respect to oxygen concentration at $653,663,673$, and $683 \mathrm{~K}$

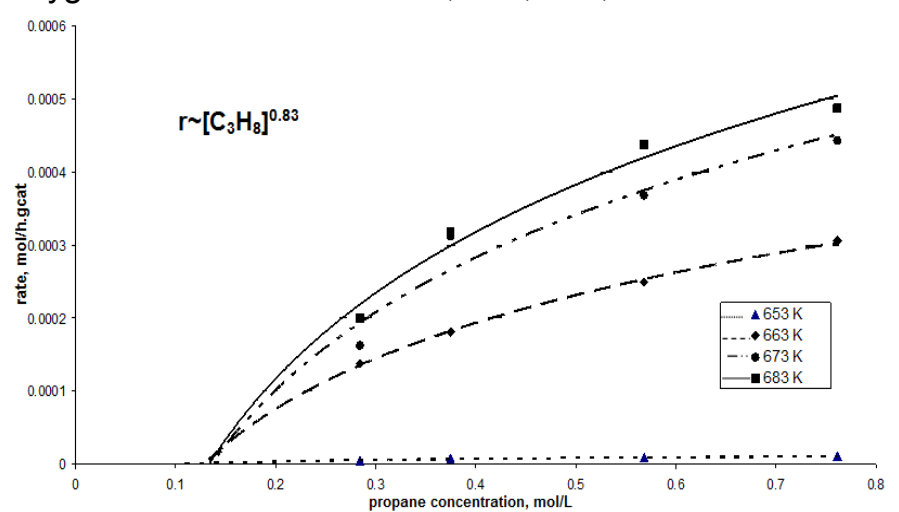

Fig 3. Rate of acetic acid formation with respect to propane concentration at $653,663,673$, and $683 \mathrm{~K}$

\section{Rate of $\mathrm{CO}_{2}$ and acetic acid formation}

Fig. 1 shows that the rate of carbon dioxide formation is first order with respect to propane concentration at all reaction temperatures. It is strong indicated that this product is formed during the gas reactant (propane) adsorbed on the catalyst surface (not in the gas phase), it means that the carbon dioxide is formed by catalytic surface reaction. Fig. 2 shows that the rate of partial oxidation of propane to carbon dioxide is partial order (0.31) with respect to oxygen concentration. It is believed that this product is produced by direct combustion of propane. But it is also possible that the product is produced from further oxidation of propane or intermediate product (acetic acid), since the order differ compare to that of propane disappearances. But, the high activation energy $(177.3 \mathrm{~kJ} / \mathrm{mol})$ which is required for the formation of carbon dioxide over this catalyst strongly indicated that carbon dioxide originates from a direct combustion of propane and not from overoxidation of acetic acid. The total oxidation of the desired product acrylic acid is a less likely contribution as its

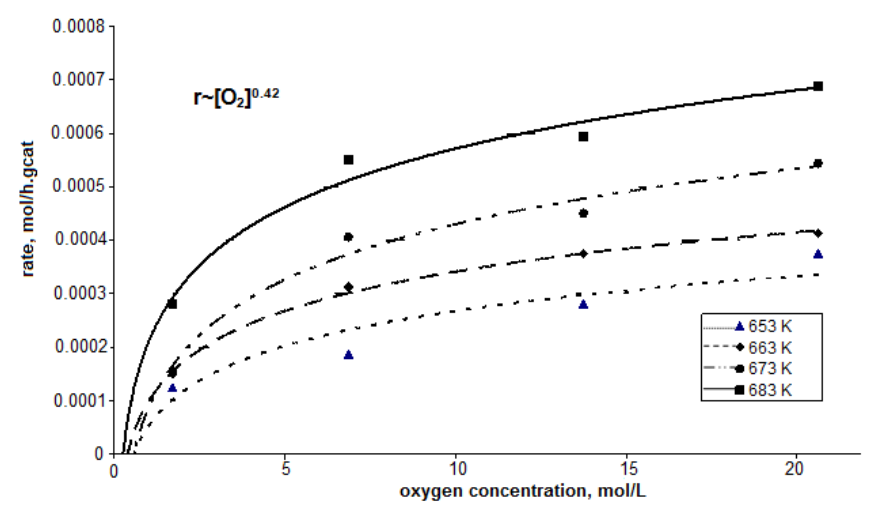

Fig 4. Rate of acetic acid formation with respect to oxygen concentration at $653,663,673$, and $683 \mathrm{~K}$

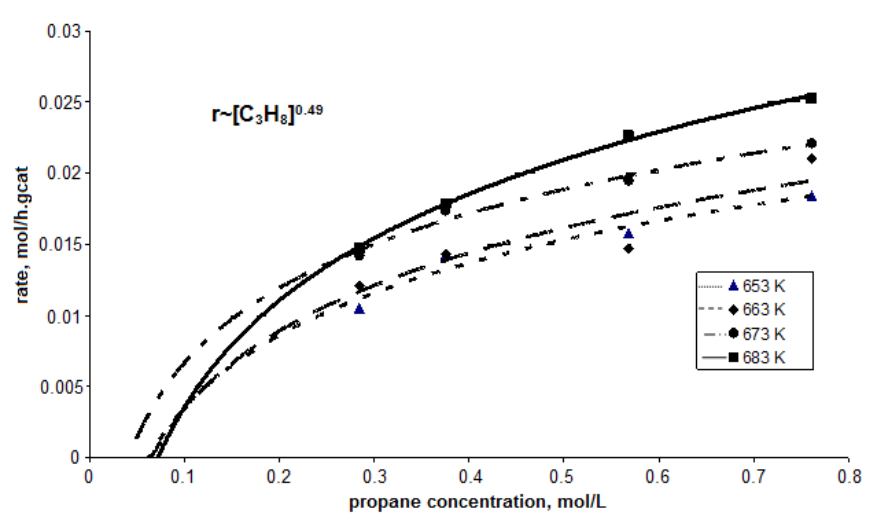

Fig 5. Rate of acrylic acid formation with respect to propane concentration at $653,663,673$, and $683 \mathrm{~K}$

formation and desorption requires smaller activation energies.

This description is supported by Fig. 3 and 4. The figures show that the acetic acid formation from oxidation of propane is not a linear function with respect to propane concentration and oxygen concentration at all temperatures. These indicate that the production of acetic acid is hindered by desorption from catalyst. During the hinder process, propane can be further oxidizing to produce carbon dioxide. The high activation energy describe that the acetic acid production is quite difficult. This is also support that acetic acid production is strongly hindered by desorption from the catalyst surface. In addition, extrapolation to zero propane concentration indicates that the curve does not pass through the origin of the graph; their rate of appearance is zero at a propane concentration is about $0.15 \mathrm{~mol} / \mathrm{L}$. The reasons for this at low propane concentration $(0.15 \mathrm{~mol} / \mathrm{L})$, an intermediate product or propane does not convert to acetic acid but it convert to other products, i.e. overoxidation to produce carbon dioxide. 


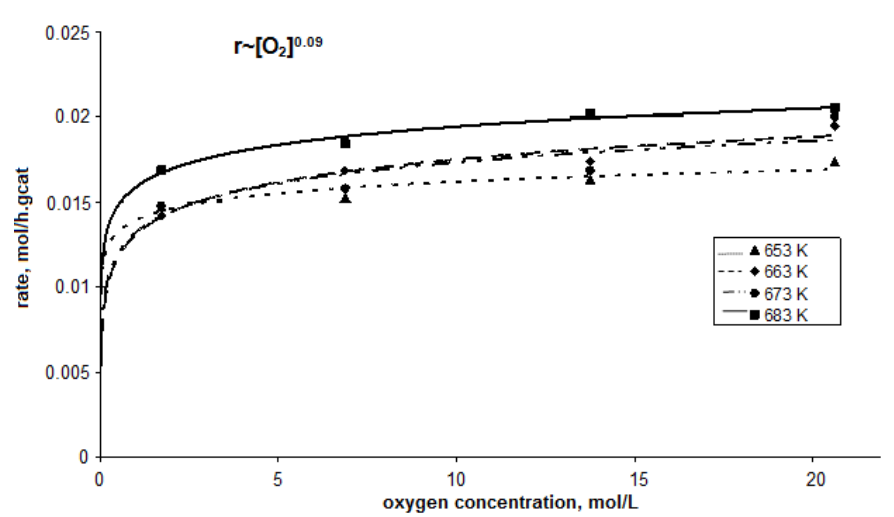

Fig 6. Rate of acrylic acid formation with respect to oxygen concentration at $653,663,673$, and $683 \mathrm{~K}$

\section{Rate of acrylic acid (AA) formation}

Fig. 5 and 6 depict that the acrylic acid formation from oxidation of propane is not a linear function with respect to propane concentration and oxygen concentration at all temperatures. In addition, extrapolation to zero propane concentration indicates that the curve does not pass through the origin of the graph; their rate of appearance is zero at a propane concentration of about $0.05-0.075 \mathrm{~mol} / \mathrm{L}$. The reasons for this is that the experimentally determined rate for a product (i.e. AA) is the difference between the true rate of formation and the rate of intermediate disappearance in deep oxidation of this intermediate. This indicates that a kinetically intermediate must exist before the formation of AA. It is believed that the intermediate is acrolein $[5,10,12]$. Because of acrolein is very easy to convert to $\mathrm{AA}$, acrolein can not be detected during the reaction. This description is supported by the activation energy of AA formation which is quite small, indicate that AA quite easy to produce from acrolein. This is also describe that the formation of $A A$ is easier than formation of acetic acid (require very high activation energy). As the activation energy for total combustion is so high it is assumed that the possibility of a fast consecutive total oxidation seems less likely than the existence of a difficult-to-form intermediate before the formation of AA.

\section{CONCLUSION}

The result supported the argument that the structure and surface texturing of MoVTeNb oxide catalyst particles composed of two phases referred to in the literature as M1 and M2 [8-9,12]. The M1 phase is the cluster that active as catalyst for the conversion of propane to acrylic acid. The leaching process using water for $1 \mathrm{~h}$ support to release the M2 phase from the catalyst. The very high activation energy of carbon dioxide formation indicates that the M2 which is responsible for total oxidation release during the leaching process. The result also shows that $A A$ quite easy produce from intermediate since the activation energy quite low.

\section{ACKNOWLEDGEMENT}

The research has been carried out in the COMBICAT Laboratory, University of Malaya, Kuala Lumpur, Malaysia.

\section{REFERENCES}

1. Boizumault-Moriceau, P., Pennequin, A., Grzybowska, B., and Barbaux, Y., 2003, Appl. Catal. A, 245, 55-67.

2. Grzybowska Swierkosz, B., 2000, Top. Catal., 1112, 23-42.

3. Grzybowska-Swierkosz, B., 2002, Top. Catal., 21, 175

4. Novakova, E.K., Vedrine, J.C., and Derouane, E.G., 2002, J. Catal., 211, 226-234.

5. Vedrine, J.C., Novakokva, E.K., and Derouane, E.G., 2003, Catal. Today, 81, 2, 247-262.

6. Widi, R.K., Hamid, S.B.A., and Schlogl, R., 2009, React. Kinet. Catal. Lett., 98, 2, 273-286.

7. Widi, R.K, 2010, Indo. J. Chem., 10, 2, 172-176.

8. Jacob, B.W., Olaf, T., Fazliana, A.H., Annette, T., Ute, W., Dang, S.S., Restu, K.W., Sharifah, B.A.H., and Robert, S., 2006, Top Catal., 39, 1-2, 51-61.

9. Widi, R.K., Hamid, S.B.A., and Schlogl, R., 2008, J. Nat. Gas Chem., 17, 2, 130-134.

10. Lin, M.M., 2001, Appl. Catal. A, 207, 1-7.

11. Botela, P., Solsona, B., Martinez-Arias, A., and Lopez-Nieto, J.M., 2001, Catal. Lett., 74, 3-4, 149155.

12. Lin, M., Desai, T.B., Kaiser, F.W., and Klugherz, P.D., 2000, Catal. Today, 61, 223-229.

13. Fogler, H.S., 1999, Elements of Chemical Reaction Engineering, $3^{\text {rd }}$ ed., Prentice-Hall Inc., New Jersey, 126. 